\title{
TURNING DISASTER INTO BUSINESS OPPORTUNITY THROUGH PROCESSING OF POTATO STICK IN SIOSAR VILLAGE KARO DISTRICT
}

\author{
Riana Friska Siahaan ${ }^{1}$, Erli Mutiara ${ }^{1 *}$ \\ ${ }^{\prime}$ Jurusan Pendidikan Kesejahteraan Keluarga, Fakultas Teknik, Universitas Negeri Medan, Medan, Indonesia \\ *Corresponding Author: erli_mutiara@yahoo.co.id
}

\begin{abstract}
The purpose of this activity is to empower the potential owned by the partner community. The activities are conducted from July to November 2017. Activity partners are Ati Rohati and home industries Wahyuni. Location of activity in Suka Meriah Village Siosar Kec. Brand Kab. Karo. This village is an area where the relocation of people affected by eruption of Mount Sinabung. Located 110 $\mathrm{km}$ from Unimed. Methods of implementation of activities are education, production training, business management training, machine use and mentoring. Output $t$ of this activity is 1) Potato Sticker Machine and 2) Potato Stick. Specifications of potato sticks are: 1) Have nutritional content: Carbohydrates, Proteins, fats, iron, and fiber; 2) Durable and hygienic. Results of activities obtained are partners have knowledge of potato stick processing, actively participating partners, skilled partners using potato sticker printing machine. Partner production is getting better and partner income is also increasing.
\end{abstract}

Keywords: Stick, Potato, Disaster, Karo

\section{INTRODUCTION}

Displaced victims of the eruption of Mount Sinabung, Karo Regency, North Sumatra already relocated in stages. The relocation was done to minimize the problems of life experienced by about 9,000 families victims of the eruption of Mount Sinabung at the evacuation site. The first phase of the relocation of as many as $370 \mathrm{KK}$ in Siosar is already finished (Adminmetro, 2016).

The Government is already relocating residents from three villages to a new location in Siosar Sub-district, Karo Regency. Third country citizens have already relocated to the territory of Siosar is a citizen of the village of Simacem, village of Bakerah, and the Like. The Government hopes gradually and independently of other refugees willing citizens relocated to Siosar (Adminmetro, 2016). In Figure 1 it can be seen the House relocation of community Siosar.

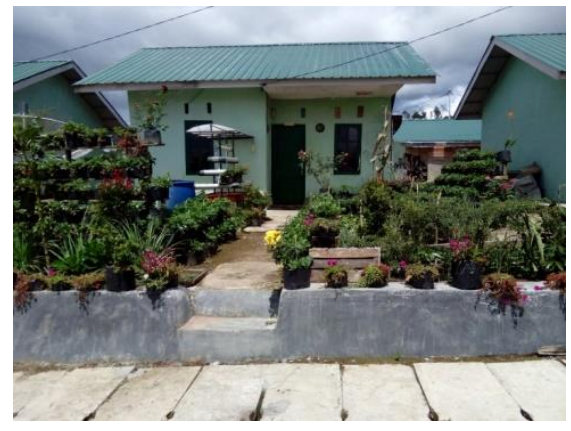

Figure 1. House of Siosar community relocation

The Government's main priorities Karo Regency, North Sumatra Province is improving the agricultural sector and tourism. Karo Regency has been blessed with fertile soil, productive and beautiful landscape that must be built and improved. As a result, the agricultural sector has become a livelihood and main source of income in down decreases over the years. However due to the eruption of Mount Sinabung beginning in 2010, the Community Board no longer can depend and survive on agriculture, (BNPB, 2016).

The sector has lost power saingnya. They need to shift the focus to small industries and services. Skills training, entrepreneurship, and increased efforts need to be undertaken to motivate people to become more economically active in business development. This activity is to enhance the entrepreneurial spirit and the ability of the public 
Agenda. A change of mindset and focus on the community. They should be more active and creative in transforming potential commodities and skills into the business as a way to enhance the life and support to his family. It is, in the end will reduce unemployment and create more job opportunities (BNPB, 2016).

One of the challenges for a small business to still exist in the global market is how to build the ability to be able to win the competition is increasingly tight. Therefore a small industry is required to enhance its ability to manage its business in a more efficient manner, making use of local potential in a more optimal and using appropriate technologies, (Dinkom, 2016).

The potato is one of the food ingredients which is currently much favored by the public, either in community or abroad. The potato is widely popular in the form of processed food, such as French fries or chips. In fact, there is a new symptom in which a potato substitute food rice because potatoes contain carbohydrates that are low $(19 \mathrm{~g} / 100 \mathrm{~g}$ of material) but can be accounted for $80 \%$ of the energy that comes from the core. In addition to containing carbohydrate, potatoes also contain minerals such as phosphorus, iron, calcium; vitamins B, C, and a little vitamin a. processed Potatoes have nutrient content which is beneficial for health as it contains enough calories, low cholesterol content, contain starch that is difficult to digest and contains no chemical substances harmful to the health of the body. Compared to rice, protein, fat and energy lower potato. When compared with other tubers such as cassava, sweet potato, taro, and nutritional composition of the potato is still relatively better (Sirulo, 2016).

The potato is the world's fourth major food crop after rice, wheat, and corn. The high nutritional value of potatoes cause a lot of areas that are producing this crop. Each family in the Siosar plant potatoes. Warga Village have been harvesting potatoes average gets results $8-8.5$ Tons of land rented area of $0.5 \mathrm{Ha}$. In the meantime, the potato commodity prices Idr 6000/Kg when sold to a reservoir that instantly came to their lands (Joon, 2016). In Figure 2. It can be seen the potato agricultural communities that can be sports become stick potato.

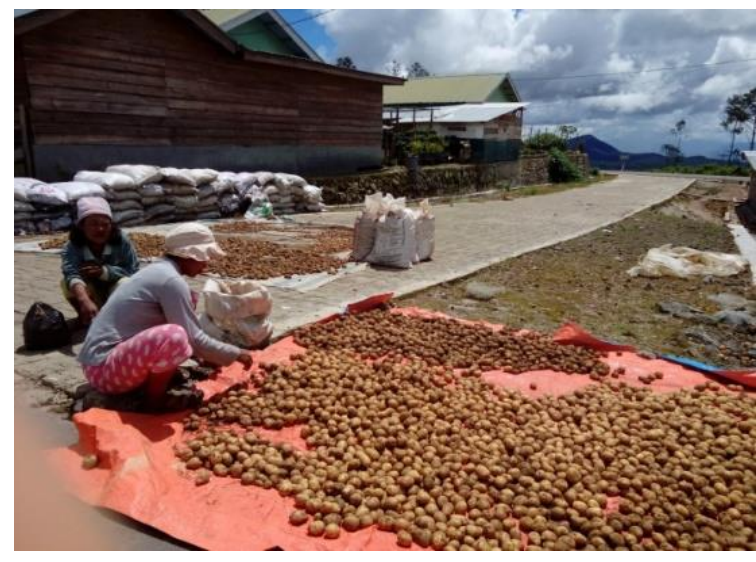

Figure 2. Potatoes of community crops

One of the activities that need to be implemented in the community is to improve the pendatan family through the processing of potato stick aimed at creating economic opportunities, especially for household industry. Pengolahan potato stick is very appropriate because raw materials manufacturing food from agricultural commodities are very much available in the local area.

\section{PARTNER PROBLEM}

The Village of Siosar in the district of Karo is the relocation zone set by the government for communities affected by the eruption of Mount Sinabung. Each family that relocated to the village gets home and agricultural land. So they can still have activity as a farmer in the vicinity of where they live. Since they occupy a house in the village of Siosar they've been planting various kinds of vegetables and fruits, because to meet the needs of their lives simply rely on of agricultural output is around their homes. Based on this to increase family income then the need to provide training to the mothers of the farmers to increase its business through the processing of potato stick. Accordingly, two major problems faced by relocated people in Siosar village are as follow:

1) Lack of skill in making the potato sticks food from raw materials available in their immediate vicinity.

2) Insufficient competency in applying techniques of packaging products that attract who is able to give a characteristic typical of who can convince prospective buyers. The issue is gaining attention because it can affect the the success of the marketing of the product.

Problems partner related aspects of management that will look for a solution the solution include:

1) The partners have not learned and skilled in Managing a effort that will was involved. The partners still very layman with the management of a business that effective and efficient. The problem is becoming a priority to guarantee the sustainability and progress the venture which will Group by partners. 
2) The partners have not learned and skilled in managing technique promotion and marketing of the products that will be generated. The partners still have yet to Figure out How to promote and market your products are good. The problem is becoming a priority because the marketing is wrong one key the success of the a the effort.

\section{SOLUTION OFFERED}

Information about some of the problems that are faced by the partners surely it must be as soon as possible to overcome as wrong one solution partner increased revenue. The team consists of community service as part of the community who is dabbling in the world of education, felt compelled to join the help provide Solutions against problems that are faced by communities affected by the relocation of the village due to the impact of the eruption of Mount sinabung. Through the program this and based on analysis of needs that have been carried out, a team of servants try to offer Solutions towards the problems of those with a touch of Ipteks, i.e. through the activities principal:

1. An increase in the the ability of the partners in making stick potatoes to satisfy the taste buds the market.

2. The use of the technology information as a marketing media products.

3. Repair of System management.

Benefits who obtained the partner from the implementation of the activities of the principal. These include:

1. Community partners can make the potatoes stick to satisfy the tastes of the market.

2. Partners have competence Management effort to run its business, so that can make strategy marketing themselves.

3. Marketing will be done either directly or through partners' media online.

\section{EXTERNAL TARGET}

This program was intended to increase quality and quantity of products made by the community. :

1. Stick-printer machine for potatoes

2. Variety of potato sticks

3. Publication in an ISSN-indexed journal

\section{METHODS AND IMPLEMENTATION}

To realize the wishes of the community partners by increasing the family income through the processing of potato stick, then it will do the phases of activity as a solution against the problems that are being faced by the partners. The activities in question will be carried out using several methods approach include socialization/education, training, and packing and marketing techniques.

For the realization of Solutions solving a problem which has to offer then the activities it will done through the five stages of the activity as follows.

\section{1) Phase I (Extension/socializing)}

On the stage of the initial partners will be given the knowledge/insight on prospects effort that will they develop, including how the techniques of production, marketing or Management efforts. The extension will be implemented by the method of lecture and discussion. The activity is aimed to be more convincing and solidify knowledge, insight and passion for starting new ventures.

\section{2) Phase II (Training Engineering Production and Packaging products)}

On the stage of this partner will be trained to make potato stick of potato yields a very rich community. During the training will be carried out activities of coaching and consulting so the partners really capable and skillfully make products that quality. Further partners are given training about ways of packaging products that 's interesting by using lebel and has characteristics typical of its own.

\section{3) Phase III (the training techniques of the promotion and marketing of products)}

On the stage of this partner will be trained and mentored in continuous on the ways of promoting and marketing the products are generated. Se up to partners to successfully market its products that can guarantee the sustainability of its business, and also use technology information as marketing media online media i.e. products.

\section{4) Stage IV (Guidance On management of enterprises)}

On the stage of this partner will be provided with tips to manage a business/venture. The activities of the done through lectures and discussions to party partner really master the concepts of the management effort which is good for ensure the existence and progress of efforts that will they get into.

\section{5) Phase V (Monitoring)}

Managing Team activities will do monitoring and mentoring in periodically to ensure the sustainability of the effort that will be developed by the partners. On the stage of this, implementing team also will conduct an 
analysis of against the possibility of problems that arose from the party 's partners during the live the effort and seek the solution.

\section{THE PARTICIPATION OF PARTNERS}

The success of the the activities of this necessarily only highly depends on the participation of Active from party partners. The participation of parties partners who are expected in the activities it is as follows:

1) Provides a special place for training.

2) Provide the raw material for processing of potato stick

3) Follow the entire activities of socialization, counselling/training processing stick potato and monitoring.

4) Committed to high to carry on and develop the venture that will be drilled.

\section{RESULTS AND DISCUSSION}

The potato (Solanum tuberosumL) has become part of Indonesia society. There are thousands of people who gave up her life with the cultivation of potatoes. Potatoes are very suitable cultivated in the Highlands. Plants that are not Woody and belongs in the Solanaceae family originated in South America and is now cultivated widely in Europe and Asian, including Indonesia. Although potatoes instead of staple food for the people of Indonesia, but consumers tend to increase from year to year because the number of products grew, the livelihood of the community increased, and foreign tourists who stay in Indonesia is increasing. As food ingredients, potatoes contain carbohydrates, a source of minerals (phosphorus, iron, and potassium), vitamin B, vitamin C and vitamin A bit.

Potatoes, other fresh circumstances, consumed in adulthood is not the least processed into various food industry so results or semi-finished. Marketing of potatoes commonly done traditionally with the marketing chain is long enough. For example, from farmers to small volume in the village and then to the big wholesale traders in major cities or between regions and then to retailers big or small, and further on to the consumer.

The implementation of this activity, carried out with methods of education, the training methods of production, business management training, use of tools and mentoring. Activities that have been carried out are the following: Dissemination activities service group partners by team devotion. Carry out the practice of processing potato stick. Granting the tools needed by the partners either devotion to the practice of processing products and printer to stick a potato that is either a printer machine of potato stick.

To improve the management of the implementing team partners provide business management training, with the aim to improve the skills of business owners (partners) in implementing the management in the areas of organization, production, finance, administration, the selling price of the product, consumer and marketing techniques. All of the activities already carried out by the implementing team gets positive feedback from partners it can be seen from an enthusiastic partner in the implementation of activities. Partners feel greatly helped by activities conducted and they expect this activity continues until the venture partners are well developed.

\section{REFERENCES}

Adminmetro. 2016. Pengungsi Sinabung Direlokasi ke Siosar. Diakses 5 Mei 2017. http://metro-online.com

Bappenas, Badan Nasional Penanggulangan Bencana (BNPB), 2016. Rencana Aksi rehabilistasi dan rekonstruksi Pascabencana erupsi gunung sinabung tahun 2013-2015.

[Dinkom] Dinas Komunikasi, Informatika dan PDE Kabupaten Karo. 2016. Data Pengungsi Erupsi G Sinabung 2013-2016. Diakses tanggal 2 Mei 2017. http://www.karokab.go.id

Prasetyo E. 2016. Pengungsi Sinabung Mulai Buka Lahan Pertanian. Diakses tgl 2Mei 2017. http://news.okezone.com.

Sirulo . 2016. Warga Relokasi Siosar Bakerah Panen Kentang Perdana. Diakses tgl 26 April 2017. http://metro.com. 